\title{
Tradition, the Self, and Substantive Due Process: A Comment on Michael Sandel
}

\author{
Robert Post $\dagger$
}

Professor Sandel's purpose is "to bring out the truth" in the view that the "justice (or injustice) of laws against abortion and homosexual sodomy depends, at least in part, on the morality (or immorality) of those practices." In particular, he wants to demonstrate that arguments against such laws cannot be carried entirely by a commitment to a "voluntarist" 2 perspective, which defends the right of individuals to choose to engage in certain practices, regardless of the moral character of those practices. Sandel's project is to illustrate the inadequacy of this perspective through a critical analysis of "actual arguments"3 contained in recent cases in which the United States Supreme Court has developed the constitutional right to privacy, which protects from certain kinds of state interference such areas of life as abortion, procreation, marriage, and contraception.

In this Comment I shall explore two problems with Professor Sandel's stimulating paper. The first is an important and suggestive ambiguity which lies at the heart of its exposition of the "voluntarist" perspective. The second is Sandel's seeming assumption that the discourse of moral and political philosophy ought to be transposed tout court into the arena of constitutional adjudication.

\section{I}

\section{The Voluntarist Perspective}

A central target of Professor Sandel's paper is what he calls the "voluntarist view," which he describes as a theory that "government should be neutral among conceptions of the good life in order to respect the capacity of persons as free citizens or autonomous agents to choose their conceptions for themselves." 4 Sandel traces a shift in Supreme

$\dagger$ Professor of Law, Boalt Hall School of Law, University of California, Berkeley.

1. Sandel, Moral Argument and Liberal Toleration: Abortion and Homosexuality, 77 CALIF. L. REv. 521, 521 (1989).

2. Sandel, supra note 1 , at 522 .

3. Id.

4. Id. 
Court decisions involving the constitutional right to privacy. He characterizes the early cases, like Griswold v. Connecticut, ${ }^{5}$ as reflecting a "traditional notion of privacy," 6 which embodies a "teleological" concern to affirm and protect "the social institution of marriage." $\mathrm{He}$ notes, however, that in its more recent cases the Court has turned instead to "voluntarist" ${ }^{8}$ grounds for the protection of privacy, grounds which celebrate the importance of individual choice.

Focusing on the recent decision of Bowers v. Hardwick, ${ }^{9}$ Sandel identifies "two different ways" in which the question of whether "homosexual intimacies" should be "entitled to a constitutional right of privacy" might be answered: "one voluntarist, the other substantive. The first argues from the autonomy the practices reflect, whereas the second appeals to the human goods the practices realize." deplores the fact that "of these two possible replies, the dissenters in Bowers relied wholly on the first." 11 In his view, the Bowers dissent reflects the Court's unfortunate recent turn toward voluntarism, with its concomitant privileging of individual choice, its ideal of "neutrality," and its rejection of "substantive moral discourse." 12

For Sandel, the voluntarist view is associated with two distinct perspectives: (1) an emphasis upon individual choice; and (2) a rejection of substantive moral discourse with a concomitant inattention to the evaluation of human goods. ${ }^{13}$ The difficulty is that these two perspectives do not necessarily entail each other. Indeed, although recent Supreme Court decisions have tended to privilege individual decisionmaking, they have also engaged in the substantive evaluation of human goods.

Justice Blackmun's dissent in Bowers perfectly illustrates this point. It is true that the dissent celebrates individual choice. It sets out to define "certain decisions that are properly for the individual to make" 14 and that should therefore "be kept largely beyond the reach of government." 15 The dissent attempts to develop the theory that the Constitution protects those specific kinds of personal decisions that are necessary for "an individual's self-definition." 16 It does so because it views "the

5. 381 U.S. 479 (1965).

6. Sandel, supra note 1, at 526 .

7. Id. at 527 .

8. Id. at 525 .

9. 478 U.S. 186 (1986).

10. Sandel, supra note 1, at 534 .

11. Id .

12. Id. at $522-23$.

13. Id.

14. Bowers, 478 U.S. at 204 (Blackmun dissenting).

15. Id. at 203 (quoting Thornburgh v. American College of Obstetricians \& Gynecologists, 476 U.S. $747,772(1986))$.

16. Id. at 205 . 
'ability independently to define one's identity [as] central to any concept of liberty." "17 The central thrust of the dissent is that identity-producing decisions are those which involve "the "emotional enrichment [of] close ties with others." "18

The dissent, however, explicitly argues that such decisions should be protected because the power to make them is essential to the realization of a positive human values. The exercise of that power is indispensable "to the happiness of individuals" and to the "richness" of intimate "relationships", 19 it is morally and practically necessary for the achievement of "a harmony in living." 20 Individual choice in the matter of sexual partners is important, in other words, not because of the abstract virtue of autonomy, but because it is a prerequisite for the creation of "human goods." Thus while it may be fair to characterize the dissent as protecting individual choice, it is certainly not fair to charge it with evading substantive moral commitments.

One can of course disagree with the dissent on these commitments; one can argue that personal happiness and harmony are inadequate grounds for constitutional decisionmaking, or that such happiness and harmony do not depend upon individual choice, or that they do not depend upon close sexual relationships. But it is evident that the dissent does attempt to make a moral argument about specific human goods, and so cannot fairly be accused of evading substantive moral judgment. In fact, by arguing that the capacity to make certain kinds of individual choices is necessary for the achievement of the human goods of happiness, harmony, and identity, and by using that argument as a basis to justify constitutional limitations on the power of the state to regulate certain kinds of private behavior, the dissent appears to be engaging in precisely the kind of "naive" view advocated by Sandel at the beginning of his paper. ${ }^{21}$

So what, then, is troubling Professor Sandel? I suspect that the root of his concern lies in the fact that the Bowers dissent understands the relevant human goods to arise from the practice of choice, rather than from the practice of homosexual intimacy. Although this distinction is not relevant to the presence or absence of substantive moral discourse, it is relevant to the question of whether that discourse will reflect a conception of persons as embedded within constitutive social practices or will instead reflect a conception of persons as independent and autonomous. I suspect that Sandel's real objection to the Bowers dissent, and indeed to

\footnotetext{
17. Id. (quoting Roberts v. United States Jaycees, 468 U.S. 609, 619 (1984)).

18. Id. (quoting Roberts, 468 U.S. at 619).

19. Id.

20. Id. (quoting Griswold v. Connecticut, 381 U.S. 479, 486 (1965)).

21. Sandel, supra note 1, at 521 .
} 
the Court's more recent substantive due process decisions, is that they "redescribed the bearers of privacy rights from persons qua participants in . . . social institution[s] . . . to persons qua individuals, independent of their roles or attachments." 22

Sandel is of course quite correct to observe that many of the Court's recent right-to-privacy decisions have focused upon ahistorical individuals, rather than upon persons who are part of traditional social institutions. The shift in the Court's focus is quite apparent from a doctrinal point of view. The Court's decisions regarding constitutional privacy are merely the most recent in a long line of cases that have developed the doctrine of substantive due process. That doctrine attempts to delineate the aspects of "liberty" which the due process clause will protect from state interference. The classic statement of the doctrine was by Justice Cardozo, to the effect that the due process clause protected those "principles of justice so rooted in the traditions and conscience of our people as to be ranked as fundamental."23 Substantive due process, in other words, classically examined the traditional and institutional bases for claims of immunity from government regulation. Justices Harlan and Goldberg addressed the issues posed in Griswold ${ }^{24}$ from within this doctrinal framework, which focused their attention, as Professor Sandel rightly notes, directly on "the social institution of marriage." 25

But this focus on tradition and institutions was strained by the Court's subsequent foray into the area of nonmarital sex. ${ }^{26}$ By the time the Court confronted the abortion cases, it had completely lost the ability to support its decision by reference to "the traditions and conscience of our people," 27 for the simple reason that abortion had for many years been proscribed virtually everywhere within the nation. To justify its conclusion in $R_{0} e^{28}$ that there was a constitutionally protected right to abortion, therefore, the Court was forced to stand classic due process doctrine on its head. It was required to articulate a justification for immunizing individuais from those government regulations that flowed precisely from the traditions and conscience of the people.

The Court thus began to focus its analysis on those rights which individuals could assert to preclude even traditional government

22. Id. at 527.

23. Palko v. Connecticut, 302 U.S. 319, 325 (1937) (quoting Snyder v. Massachusetts, 291 U.S. 97, 105 (1933) (Cardozo, J., writing for the Court)).

24. 381 U.S. 479, 500 (1965) (Harlan, J., concurring and incorporating by reference his dissenting opinion in Poe v. Ullman, 367 U.S. 497 (1961)). Id. at 486 (Goldberg, J., concurring).

25. Sandel, supra note 1 , at 527.

26. See, e.g., Eisenstadt v. Baird, 405 U.S. 438 (1972).

27. Snyder, 291 U.S. 97, 105 (1933) quoted in Palko, 302 U.S. at 325, and in Griswold, 381 U.S. at 487 (Goldberg J., concurring).

28. 410 U.S. 113 (1973). 
restraints. For obvious reasons, this analysis stressed the autonomy of individuals, rather than their dependence upon tradition and culture. It is this turn toward autonomy and choice that Professor Sandel rightly observes in his essay. What he fails to acknowledge, however, is that-as is often the case in the law-classic due process doctrine was never explicitly overruled. Although it receded from prominence, it nevertheless retained its legitimacy. ${ }^{29}$ As a result we find that in the Bowers decision the Court majority was able to invoke classic due process doctrine to argue that homosexual practices were not "deeply rooted in this Nation's history and tradition," 30 while the dissent was able to rely upon the Court's more recent cases to argue that such practices constitute the kind of "decisions that are properly for the individual to make." 31

The contrast between these doctrinal frameworks, of course, resonates deeply with Professor Sandel's famous critique of John Rawls, in which he faulted Rawls for conceiving of the self as detached and disembodied. $^{32}$ In that critique Sandel eloquently demonstrated the inadequacy of any individualism that postulates the self as totally independent of its community, tradition, and culture. We have learned from Professor Sandel that the self precedes its own choices, and that it in this way constituted by its community. It is no wonder, then, that Professor Sandel should be sympathetic to the doctrinal framework of Justice Harlan in Griswold, with its focus on social practices and institutions, for that framework represents precisely the kind of reflective self-discovery one might expect of a self embedded within a cultural tradition.

Sandel's objection to the Court's recent voluntarist perspective may thus stem less from its lack of substantive moral discourse, than from its underlying conception of persons as independent of their roles and attachments. It is the Court's individualism that rankles, the fact that the Court conceives intimate relationships as entirely the product of personal choice rather than of the institutions which are partly constitutive of the persons who participate within them. By shifting its focus from social practices to individual decisions, the Court's more recent doctrine effectively ignores those intersubjective "roles or attachments" 33 which, on Sandel's view, are the crucible of moral identity.

Even if one accepts Sandel's basic view of moral identity, however, it does not follow that the Court's recent doctrinal focus on individual choice is illegitimate. I do not understand Sandel to argue that the justice or injustice of regulating practices like homosexual sodomy depends

\footnotetext{
29. See, e.g., Moore v. East Cleveland, 431 U.S. 494 (1977).

30. Bowers v. Hardwick, 478 U.S. at 192 (1986).

31. Id. at 204 (Blackmun, J., dissenting).

32. M. SANDEl, Liberalism AND the Limits of Justice (1982).

33. Sandel, supra note 1 , at 527.
} 
entirely on the moral status which such practices have traditionally been accorded. Thus even though the practice of homosexual sodomy has traditionally been condemned, and even though a good many persons have incorporated into their identity negative attitudes toward that practice, Sandel properly regards the moral status of the practice as open to debate. ${ }^{34}$ Sandel hence appeals to a "substantive moral discourse" which is not confined to traditional attitudes and attachments.

The theoretical foundation for such a discourse has been well explored by the American sociologist George Herbert Mead, who in the early years of this century advanced a sophisticated and complex view of the self as constituted by its social environment. Mead argued that the self can only exist by virtue of a linguistic competence which internalizes the values and attitudes of others. The self as a structure, as a personality, Mead labelled the "me." But Mead also understood that the self cannot be reduced to the "me," for that would render the self totally passive and transparent. At any given moment individuals have the capacity to distance themselves from who they are, or who they have been made, and to reflect on these facts and perhaps even to change them. Mead labeled this capacity the "I," and he viewed the self as a process of interaction between the "I" and the "me." Any healthy self must have both an "I" and a "me," for it must simultaneously have shape and grounding in a specific culture and tradition, and yet be able to reflect on and criticize that tradition. ${ }^{35}$

It follows from this perspective that an emphasis on individual choice-on the "I"-is not necessarily incompatible with a proper respect for the culture and tradition of the embedded self-the "me". In fact, we should expect in both our moral philosophy and our law a balance between these two aspects of the self. Not surprisingly, that is just what we find in the contemporary doctrine of substantive due process. Older versions of the doctrine focus on and protect the "me," by safeguarding from state interference the norms and values by which the social self has been constituted. More recent versions of the doctrine focus on and protect the "I," by offering individuals a clear and protected space to step back, evaluate, and perhaps differ from received moralities. Just as Professor Sandel would himself preserve a neutral space for a "substantive moral discourse" that can be critical of traditional attitudes, so the voluntarist focus which so disturbs him can be understood as an effort to secure the same protection for homosexuals to live and act in a manner critical of received traditions.

There remains, of course, the decisive question of whether, in any particular case, the law should speak for the "I" or the "me"; whether it

34. Id. at 536 .

35. G. Mead, ON Social Psychology 226-40 (A. Strauss rev. ed. 1964). 
should reinforce the claims of tradition and culture or instead defend the ability of individuals to differ from that culture. On that question I agree entirely with Professor Sandel: it all depends on an analysis of the specific issue, in all of its ramifications. But should the Court decide in any particular case to defend individual choice, it would not necessarily follow that it was under the sway of an inaccurate and unduly narrow vision of the self. In any moderately complex legal system, just as in any moderately sophisticated person, we should expect a complicated process of exchange between the "I" and the "me," between the claims of individualism and those of community. This exchange cannot be encapsulated by any single decision, or even by any single line of decisions. To truly support Sandel's charge that modern substantive due process law is unduly individualist, therefore, would require the assessment of a total pattern of decisions.

II

The Discourse of Political Philosophy and the Practice of Constitutional AdJUdication

This analysis, it should be noted, rests on a very different image of constitutional law than that which informs Professor Sandel's essay. Sandel's tendency is to read specific opinions as expositions of philosophical positions, and he understands these positions to be generative of the law. He thus views judicial opinions as properly subject to full philosophical evaluation, as though judges were ersatz (and untrained) philosophers.

I am suggesting, however, that it is important to examine what judges do as well as what they say, and that what they do is revealed in patterns of judgments. As substantive due process doctrine itself nicely illustrates, important questions of constitutional law generally bestride competing doctrinal positions that draw upon distinct philosophical perspectives. The resulting ambiguities are characteristically used by judges to shape overall patterns of constitutional interventions. To uncover the philosophical perspectives that are actually generative of constitutional law, therefore, is as closely analogous to the problem of interpreting a series of actions, as it is to the challenge of interpreting a series of essays.

Of course action and articulation are closely interrelated in the law. But they are not identical. The law, unlike philosophy, is an instrument of governance, a tool for the control of behavior. If the authority of philosophical discourse depends upon the persuasive force of its reasoning, the authority of law rests ultimately upon the power of the state. I vividly remember Robert Cover at a conference remarking on the question of why legal scholars pondered so carefully the words of then-Chief Justice Burger. It was not, said Cover, because the Chief Justice was so deep 
a thinker or so talented a writer, but because his judgments were enforced by the United States Army. His words were written, so to speak, in blood. In that very real sense, to decide a constitutional case is to assume the responsibility and obligations of action.

What is at stake in a constitutional opinion, therefore, is very different from what is at stake in a philosophical discussion. It follows that the question of the regulation of private sexual practices will look very different to a moral philosopher, whose primary concern is to provide a convincing account of the ethical propriety of such regulation, than to a Supreme Court Justice, whose primary concern is to determine whether or not to strike down the regulation as unconstitutional. At times, however, Professor Sandel writes as if the latter enterprise turns entirely on the former. He remarks, for example, that "The cure for liberalism is not majoritarianism, but a keener appreciation of the role of substantive moral discourse in political and constitutional argument." 36 Likewise, in his closing pages, he defends this position because of "the extent to which constitutional discourse has come to constitute the terms of political discourse in American public life." ${ }^{37}$ Professor Sandel apparently desires judges to speak more like moral philosophers.

It may, however, be a mistake to advocate such a fusion of constitutional and moral discourse. Although it is fair to note the extent to which the former draws upon the latter, it is also important to recognize the extent to which constitutional discourse, as a form of action, has been fashioned in a manner designed to reduce possible abuses of power. Constitutional discourse is thus subject to a whole series of restraints, which are generally articulated in the language of "deference," "precedent," and so forth, which cut against the free play of moral reasoning. The nation sometimes suffers when these restraints are removed, as Franklin Roosevelt learned to his chagrin when the Court disabled his New Deal in the name of a constitutional discourse that drew heavily and without reservation upon moral presuppositions.

This is not the time to address the particular constraints that ought to placed on constitutional discourse. The subject is immensely difficult and has consumed the best efforts of the past several generations of constitutional scholars. My only point is a simple one: The blending of ethical, political, and constitutional discourse, which apparently forms the ideal of Professor Sandel's approach, may be neither a defensible nor desirable possibility for judicial decisionmaking. At the very least, a great deal of work needs to be done before that ideal can be taken as established.

36. Sandel, supra note 1 , at $\mathbf{5 2 2}$.

37. Id. at 538 . 